\title{
Proximate and Quantitative Phytochemical Analysis of Aframomum chrysanthum
}

\author{
N. Nwachoko1, E. B. Essien², E. O. Ayalogu² \\ ${ }^{1}$ Department of Chemistry (Biochemistry Unit), Rivers State University of Science and Technology, \\ Nkpolu-Oroworukwo, Port Harcourt, Nigeria \\ ${ }^{2}$ Department of Biochemistry, University of Port Harcourt, Choba, Nigeria \\ Email: blessedconfidence@yahoo.com
}

Received 5 May 2015; accepted 23 May 2015; published 27 May 2015

Copyright (C) 2015 by authors and OALib.

This work is licensed under the Creative Commons Attribution International License (CC BY).

http://creativecommons.org/licenses/by/4.0/

(c) (i) Open Access

\begin{abstract}
This work investigates the proximate and quantitative phytochemical composition of Aframomum chrysanthum (AC). The result of proximate analysis showed carbohydrate composition of $(65.44 \%$ $\pm 1.7 \%)$ to be the highest component, followed by crude protein $(13.10 \% \pm 1.2 \%)$ and ash with the least value $(2.28 \% \pm 0.1 \%)$. Quantification of the revealed phytochemical component showed the concentration $(\mu \mathrm{g} / \mathrm{ml})$ of the following in the order: alkaloids $>$ flavonoids $>$ tannins $>$ phenol. The study provided needed information on the nutritional and phytochemical composition of AC.
\end{abstract}

\section{Keywords}

\section{Aframomum chrysanthum, Proximate, Phytochemicals}

\section{Subject Areas: Biochemistry}

\section{Introduction}

Plants are a source of large amount of drugs comprising of different groups such as antispasmodics, emetics, anticancer and antimicrobials. A large number of plants are claimed to possess the antibiotic properties in traditional medical practice and are used exclusively [1]-[3]. Phytochemicals are chemical compounds that naturally occur in plants. They include alkaloids, flavonoids, tannins, phenol, and glycosides. These components are responsible for the numerous activities of plants, such as anti-diarrhoea, anti-diabetics, anti-cancer amongst others [1] [2] [4] [5].

Aframomum chrysanthum (AC) is native to tropical Africa. Aframomum is the largest African genus of the Zingiberaceae family with about 70 species where chrysanthum is included. They are found in tropical forests and savannahs, where they form dense clumps. The leafy shoots are eaten by wildlife, such as gorillas and elephants [4]. Aframomum chrysanthum is used as spices in food and drinks. It is called Urioma by Ika people of 
Delta State. [6] reported that the phytochemical composition of Aframomum melegueta (AM), a specie in the same genus with chrysanthum that may be exploited for local development of antimicrobials. They noted that the presence of phenolic compounds in the seed of AM indicates that the plant is an antimicrobial agent because phenols and phenolic compounds have extensively been used in disinfections. [7] tested the anti-microbial effects of AM on five pathogenic bacteria (Bacillus cereus, Staphylococcus aureus, Eschericia coli, Salmonella typhiand Klebsiella pneumonia) and reported that AM extract was inhibitory to the growth of Klebsiella, Pneumonia and Salmonella typhi.

This work is aimed at the determination of proximate and quantitative phytochemical composition of Aframomum chrysanthum.

\section{Materials and Methods}

\subsection{Plant Material}

Aframomum chrysanthum seeds (AC) was obtained from Ekuku-Agbor in Ika South Local Government of Delta State, Nigeria. The plant was identified by Dr. O.B. Green in the Department of Applied and Environmental Biology, Rivers State University of Science and Technology, Nkpolu-Oroworukwo, Port Harcourt, Nigeria. The sample was air dried and ground to powder form prior to analysis.

\subsection{Proximate Analysis}

\subsubsection{Moisture Content [8]}

Procedure: A clean flat dish was dried for 15 mins at $105^{\circ} \mathrm{C}$. It was allowed to cool in the desiccator for 15 mins and weighed $\left(\mathrm{W}_{1}\right) .2 \mathrm{~g}$ of well mixed sample was transferred to the dish $\left(W_{2}\right)$. The dish was cleaned and placed in the oven at $105^{\circ} \mathrm{C}$ for 4 hrs. Later, the dish was removed, covered and placed in the dessicator and allowed to cool for 15 mins, weighed as quickly as possible $\left(W_{3}\right)$.

$$
\% \text { Moisture }=\frac{\left(W_{2}-W_{3}\right)}{\left(W_{2}-W_{1}\right)} \times 100
$$

\subsubsection{Ash and Mineral Content [8]}

Procedure: Crucibles are placed in a muffle furnace for 15 mins or more. Then, they are removed and placed in a dessicator for 30 mins to cool off and weighed. $2 \mathrm{~g}$ of each sample is weighed into different dishes (crucibles). The dishes are placed on a hot plate under a fume chamber and slowly the temperature is increased until smoking ceases and the sample becomes thoroughly charred. Then, the dishes are placed at the centre of the muffle furnace and ash until fully ashed (when there is notice of grey colour of ash). After which the dishes with the ash were placed in dessicators and allowed to cool and weighed.

Let weight of the sample $=W_{1}$

Let weight of the ask $=W_{2}$

$$
\% \text { Ash }=\frac{W_{2}}{W_{1}}=100
$$

\subsubsection{Fat/Oil Content [8] Method A: Soxhlet Extraction Method (Used for Solid Products)}

Procedure: $5 \mathrm{~g}$ of dry samples were weighed after moisture determination and transferred into the thimble. 250 $\mathrm{ml}$ of a round bottom flask washed and dried at $105^{\circ} \mathrm{C}$ for 30 mins and cooled at room temperature in a dessicator and later weighed. Each thimble containing each sample was placed in an extractor, $150 \mathrm{ml}$ of ethyl ether was measured into the round bottom flask and the extractor was set up. The condenser was connected to a water tap and the extractor was set up. The condenser was connected to a water tap and the heating mantel was turned on and then fats were extracted for 6 hrs, and the solvent (ethyl ether) recovered. The round bottom flask were placed in an oven at $105^{\circ} \mathrm{C}$ for 30 mins and later placed in the dessicator to cool and the weight noted Fat: (\%)

$$
\frac{W_{t} \text { of fat }}{W_{t} \text { of sample }} \times 100
$$




\subsubsection{Crude Protein/Nitrogen}

\section{Procedure}

Digestion: $0.5 \mathrm{~g}$ of the prepared samples were weighed onto a quarter size filter paper and transferred to a kjedahl digestion flask. 1\% tablet of the catalyst was added and $15 \mathrm{ml}$ of concentrated sulhuric acid was also added into the flask. The flask was heated gently in an inclined position under a fume until frothing ceases, it is boiled briskly until the digest is clear under a fume cupboard, it is then allowed to cool and made up to $100 \mathrm{ml}$ volume using distilled water.

Distillation: $10 \mathrm{ml}$ of the digest is taken into the distillation flask, $10 \mathrm{ml}$ of $45 \%$ sodium hydroxide solution is added. The flask is then connected to a distillation apparatus before making alkaline. Ammonia was steam distilled into $5 \mathrm{ml}$ boric acid indicator in a $100 \mathrm{ml}$ conical flask, $50 \mathrm{ml}$ of the distillate is then collected.

Titration: Standard acid $(0.05 \mathrm{~N}) \mathrm{H}_{2} \mathrm{SO}_{4}$ was titrated. A blank titration was carried out using a quarter size filter paper.

$\%$ crude protein $=\% \mathrm{~N} \times$ protein factor.

Nitrogen factor $(\mathrm{N})=1.4$, protein factor $=6.25$

$$
\% N=\frac{\text { Sample Titre }- \text { Blank Titre } \times N \text { of acid } \times 1.4}{\text { Weight of Sample }(\text { in } 10 \mathrm{ml})}
$$

\subsection{Phytochemical Quantification}

[8] [9] Method was adopted for preparation/extraction of sample for GC quantitative analysis.

Twenty grams (20 g) of the homogenized sample was mix with $60 \mathrm{~g}$ of anhydrous sodium sulphate in agate mortar to absorb moisture, the homogenate was placed into a $500 \mathrm{ml}$ beaker and $300 \mathrm{ml}$-hexane was added for extraction using EPA 3540 method for 48 h. Crude extract obtained was evaporated with a rotary vacuum evaporator at $400^{\circ} \mathrm{C}$ to dryness, residue was then transferred with n-hexane onto a $5 \mathrm{ml}$ florisil column for clean up.

\section{Florisil Clean up}

Transferred residue was heated in an oven at $130^{\circ} \mathrm{C}$ overnight $(15 \mathrm{~h})$ and transferred to a $250 \mathrm{ml}$ size beaker and placed in a desiccator. $0.5 \mathrm{~g}$ anhydrous $\mathrm{NaSO}_{4}$ was added to $1.0 \mathrm{~g}$ of activated florisil (magnesium silicate) (60 $1000 \mathrm{mn}$ mesh) on an $8 \mathrm{ml}$ column plugged with glass wool. The packed column was filled with 5 ml n-hexane for conditioning. The stopcock was open to allow n-hexane run out until it just reaches top of sodium sulphate into a receiving vessel whilst tapping gently the top of the column till the florisil settled well in the column, the extract was transfer on to the column with disposable Pasteur pipette from an evaporating flask. $1 \mathrm{ml}$ portion of n-hexane was added to column to elute. Dry eluate was dissolved in $1 \mathrm{ml} n$-hexane for gas chromatographic analysis.

\section{Results}

Results obtained for proximate and phytochemical composition of Aframomum chrysanthum are as shown in Table 1 and Table 2.

\section{Discussion}

Plants have been known worldwide to be source of large amount of drugs, comprising of different groups. Harnessing thoroughly the usefulness of any plant involves the determination of its components. This work investigated the proximate and quantitative phytochemical composition of Aframonum chrysanthum (AC).

Table 1 showed the proximate composition of AC. The result showed carbohydrate composition (65.44 $\pm 1.7 \%)$ to be the highest component, followed by crude protein $(13.10 \% \pm 1.2 \%)$ and ash with the least value $(2.28 \% \pm 0.1 \%)$. Comparing this result with the proximate analysis of Aframomum melegueta specie in the same genus with chrysanthum as reported by [10], it was observed that Aframomum melegueta had percentage carbohydrate value of 71.8 while in chrysanthum it was $65.2 \pm 1.7$. Percentage values of protein and moisture were higher in chrysanthum than that of melegueta. Percentage ash value was lower in chrysanthum compared to that of melegueta.

Table 2 showed the quantitative phytochemicals of AC. The quantified components show the concentration of the phytochemicals (ug/ml) of AC in this order: alkaloids $>$ flavonoids $>$ tannins $>$ phenol. The phytochemical 
Table 1. Proximate Composition of Aframomum chrysanthum.

\begin{tabular}{ccc}
\hline Parameters (\%) & Aframomum c. \\
\hline Moisture & $12.03 \pm 0.5$ \\
Ash & $2.28 \pm 0.1$ \\
Protein & $13.10 \pm 1.2$ \\
Fat & $7.16 \pm 0.1$ \\
\hline
\end{tabular}

The table above showed the result of proximate analysis of Aframomum chrysanthum. Values are means \pm SD.

Table 2. Quantitative Phytochemical Composition of Aframomum chrysanthum.

\begin{tabular}{ccc}
\hline Component & Sub-class & (\%) Concentration \\
\hline Flavonoids & & 4.70 \\
& & 26.56 \\
2.34 & 3.58 \\
& Naringerin, Catechin, Kaempferol, & 6.10 \\
Total & Epicatechin, Rutin & $\mathbf{4 3 . 3 2}$ \\
Alkaloids & Lunamarine & 55.54 \\
Tannins & & 1.05 \\
Phenol & & 0.13 \\
\hline
\end{tabular}

The table above showed the result quantitative phytochemical composition of Aframomum chrysanthum.

result revealed naringerin, catechin, kaempferrol, epicatechin and rutin as sub-classes of flavonoid and lunamarine as a sub-class of alkaloid. The result is similar to that obtained by [11] on Aframomum melenguta which indicated tannins, alkaloids, phenols, and flavonoids. [10] [12] also reported that Aframomum melegueta contains saponnins, tannins, alkaloids, and flavonoids. This study (proximate and quantitative phytochemical analysis of Aframomum chrysanthum) has provided needed information on the nutritional and phytochemical composition of the lesser known member of the Aframomunm class Aframomum chrysanthum. The presence of alkaloids and flavonoids at high concentration affirms the plant a medicinal plant and a potential source of large amount of drugs [1] [2] [13].

\section{References}

[1] Das, K., Tiwari, R.K.S. and Shrivastava, D.K. (2010) Techniques for Evaluation of Medicinal Plant Products as Antimicrobial Agent: Current Methods and Future Trends. Journal of Medicinal Plants Research, 4, 104-111.

[2] Chiejina, N.V. and Ukeh, J.A. (2012) Antimicrobial Properties and Phytochemical Analysis of Methanolic Extracts of Aframomum melegueta and Zingiber officinale on Fungal Diseases of Tomato Fruit. Journal of Natural Sciences Research, 2, 10-15.

[3] Okwu, D.E. (2009) Phytochemical, Vitamin and Mineral Content of Two Nigerian Medicinal Plants. International Journal of Molecular Medicine and Advance Science, 1, 375-381.

[4] Tane, P., Tatsimo, S.D., Ayimele, G.A. and Connolly, J.D. (2011) Broactive Metabolites from Atramemum Species, 11th Edition. Symposium Book of Proceedings, 55, 214-223.

[5] Wikipedia, 2012.

[6] Oyagade, J.O., Awotoye, O.O., Adewunmi, J.T. and Thorpe, H.T. (1999) Antimicrobial Activity of Some Nigerian Medicinal Plants, Screening for Antibacterial Activity. Journal of Bioscience Research Communication, 11, $193-197$.

[7] Oladunmoye, M.K. and Dada, E.O. (2007) Comparative Studies on the Antimicrobial Activity of Leaf Extracts from Aframomum melegueta. Research Journal of Botany, 2, 95-107.

[8] AOAC (1990) Official Methods of Analysis. 14th Edition, Association of Analytical Chemist, Arlngton, 503-515.

[9] Herbone, J.B. (1973) Phytochemical Methods. Chapman \& Hall Ltd., London, 188. 
[10] Michael, C.D. and Ahamefula, E.N. (2012) Comparative Study of Proximate, Phytochemical and Mineral Compositions of Edible Plant Fruits/Seeds from Nigerian Rainforest. International Journal of Biolobical and Chemical Sciences, 6(4): 1905-1909.

[11] Doherty, V.F., Olaniran, O.O. and Kanife, U.C. (2010) Antimicrobial Activities of Aframomum melegueta (Alligator Pepper). International Journal of Biology, 2, 126-131.

[12] Ncube, N.S., Afolayan, A.J. and Okoh, A.I. (2008) Assessment Techniques of Antimicrobial Properties of Natural Compounds of Plant Origin: Current Methods and Future Trends. African Journal of Biotechnology, 7, 1797-1806.

[13] Inegbenebor, U., Ebomoyi, M.I., Onyia, K., Amadi, K. and Algbiremolen, A.E. (2009) Effect of Alligator Pepper (Aframomum melegueta) on First Trimester Pregnancy in Sprague Dawley Rats Nigeria. Journal of Physiological Science, 24, 161-164. 